\title{
Dos irmãos Lumière a Pathé e Gaumont
}

Maikon Augusto Delgado ${ }^{1}$

Se é preciso qualquer trabalho escrito, deve-se esperar que tudo o que tenha sido escrito possa ser justificado; nesse caso esta resenha também deveria sê-lo. Relevando-se isso, os únicos problemas aqui seriam o como e o porquê. Contudo, muitos crêem (o contrário) que o assunto de que trata esse texto não precisa de nenhuma justificativa. Não que ele se baste a si mesmo, dizê-lo seria querer receber uma refutação imediata, mas o próprio passar do tempo já o tornou realizável. O que se pretende abordar aqui não é nada mais nada menos que o próprio cinema francês. Fá-lo-ei em resposta ao pedido, feito por um amigo, de que eu escrevesse algo sobre alguma coisa que estivesse lendo. Questionei-me então: "o que é que eu estou lendo que, por ter me arrebatado, poderia ser comentado para gerar o mesmo fim, em outro leitor? A resposta que me dei foi esse livro, um achado. Não creio que haja muitos deles espalhados por aí. Acho, além disso, que os que vierem a lê-lo terão em suas mãos uma coletânea de ensaios sobre o cinema que é fruto de um trabalho muito bonito editado pela Cinemateca Brasileira e que deveria, ao menos, ser contemplado como um esforço nobre por parte de todos aqueles que a escreveram. O que farei aqui não é muito mais que comentar um pouco os quatro primeiros artigos desta obra que contém cerca de 28 textos. Espero fazê-lo de forma a vir agradar aquele que porventura se interessar por ele.

História do Cinema Francês (1895-1959) é composto por uma série de artigos de autores brasileiros e de um ou dois autores franceses, todos escritos em português e cronologicamente relacionados, a fim de contar um pouco do que poderia ser a "história linear" do cinema francês.

Como não poderia ser de se esperar, ele começa com um ensaio sobre a família Lumière, sobretudo os irmãos Lumière. Já é de praxe lermos por aí que foram eles

${ }^{1}$ Graduação - Filosofia/UFPR

130 
os primeiros a fazer cinema. No entanto, por que são tidos como os responsáveis pela criação do Cinema? O que levou a maioria dos teóricos da sétima arte a afirmarem que foram estes os dois que a criaram, sendo que havia muitos outros "fotógrafos" pesquisando a melhor maneira de conseguir transmitir o movimento de um objeto para a película? Na verdade, alguns anos antes dos Lumière, Janssen, Muybridge e Marey já o haviam feito. Não obstante, a resposta é bem clara, apesar de parecer um tanto quanto arbitrária: em 28 de dezembro de 1895, em Paris, acontece a primeira apresentação pública de L'arrivée du train, organizada pelos irmãos Lumière, contendo alguns dos elementos pelos quais se pode chamar o cinema de cinema. Ou seja, foi esse o primeiro momento onde pudemos relacionar o filme e o público, produzindo esse fenômeno artístico como o conhecemos atualmente.

O ponto importante de Os irmãos Lumière, de Rudá Andrade, é sua tentativa de mostrar a importância que tiveram para o desenvolvimento do cinema em geral, sobretudo o francês. Em contrapartida, parece ser claro para muitos dos críticos de cinema de que o fundamental de toda a obra dos Lumière foi sua pesquisa em prol do desenvolvimento técnico-fotográfico do cinema, o que é um pouco contestado pelo autor.

O segundo artigo dessa coletânea, de autoria de Sérgio Lima, um pouco em concordância com o anterior, aborda justamente o cinematografista francês Georges Méliès. Lima pretende demonstrar, em oposição ao papel dos irmãos Lumière, de forma a não querer menosprezá-los, a preocupação que Méliès teve não só com a pesquisa técnico-cinematográfica mas também com o fato de explorar outras possibilidades que o cinema parecia lhe oferecer. Méliès conseguiu enxergar o "cinema contador de histórias", e não somente aquele "cinema testemunha fiel de um acontecimento". Imagine-se, por conta disto, o salto qualitativo que o cinema não deu, e o número de portas que não foram abertas a todos os outros cinematografistas posteriores a ele. Nesse ensaio, intitulado Georges Méliès, fica bem clara a maneira pela qual o francês introduziu o absurdo e o fantástico na 
cinematografia. Seus filmes todos contavam histórias maravilhosas e muitas vezes absurdas, permeadas de um maniqueísmo bem detectado por Lima, que poderiam muito bem ser inseridas em um contexto um pouco mais amplo, como por exemplo o da transição do final do século XIX e começo do XX. Creio eu que não seria incorrer em um erro pensar em Jules Verne quando se assiste uma obra de Georges Méliès.

O texto que se segue a esse trata de um dos homens mais interessantes da história do cinema francês. Trata-se de um desenhista e cinematografista chamado Émile Cohl, alguém muito importante e pouco conhecido. Ele foi o primeiro, ou melhor, foi ele o criador do desenho animado na França. Suas criações mais célebres foram Fantasmagorie, Le cauchemar du Fantoche, Histoire des Chapeaux e Les légumes vivants. Émile Cohl também inventou, segundo Sérgio Lima, autor desse terceiro texto intitulado Émile Cohl, o handcap - uma técnica que consiste em gravar uma cena após a outra interrompendo-as a cada segundo, a fim de que elas, quanto colocadas em movimento pelo cinematógrafo, possa produzir um efeito semelhante àquele de um filme contínuo. Esta técnica é geralmente usada na feitura de filmes de bonecos modeláveis

O quarto ensaio comenta um pouco a trajetória de duas grandes distribuidoras de filmes na França, a Pathé e a Gaumont. Vários cinematografistas famosos trabalharam em pelo menos uma delas, ou até em ambas, inclusive Émile Cohl, e a importância delas é vital para todo o desenrolar da história do cinema francês. Todo o film d'art foi rodado nos seus estúdios, cujo período poderia ser fixado do início do século XX até meados da década de 20. Na época em que os nickelodeons, que obtiveram um enorme sucesso devido ao caráter de suas produções populares, eram produzidos alucinadamente nos Estados Unidos, a Pathé e a Gaumont criavam as suas bases no mercado cinematográfico francês. Homens como Capellani, Zecca, Lépine, Boireau e Feuillade, que é o criador do seriado Fantômas, realizaram boa parte de seus filmes, senão a maioria, nos seus domínios. 
Para aqueles amantes do cinema em geral, ou simplesmente para aqueles curiosos que um dia tiverem a vontade de ler algo sobre o cinema francês, História do Cinema Francês (1895-1959) é um bom começo. Esta obra contém um pequeno apêndice de fotos e uma lista bem detalhada da produção cinematográfica na França, desde 1895 até o final da década de 60, podendo se encontrar textos referentes desde aos irmãos Lumière e Méliès até a Nouvelle Vague, por exemplo.

História do Cinema Francês (1895-1959); Cinemateca Brasileira; s.d.; s. ed. 